\title{
Enhancement of Growth Parameters and Productivity of Basmati Rice through Summer Green Manuring and Zinc Fertilization
}

\author{
Amarpreet Singh ${ }^{1,2}$ and Yashbir Singh Shivay ${ }^{1}$ \\ ${ }^{1}$ Division of Agronomy, Indian Agricultural Research Institute, New Delhi (110 012), India \\ ${ }^{2}$ Presently Division of Crop Production, Central Research Institute for Jute and Allied Fibres, Barrackpore, Kolkata, \\ West Bengal (700 120), India
}

\section{Article History}

Manuscript No. AR1019

Received in $12^{\text {th }}$ November, 2014

Received in revised form $26^{\text {th }}$ November, 2014

Accepted in final form $7^{\text {th }}$ December, 2014

\section{Correspondence to}

"E-mail: ysshivay@hotmail.com

\section{Keywords}

Basmati rice, correlation, green manuring, growth, yields, zinc

\begin{abstract}
Field experiments were conducted during summer and rainy (kharif) seasons (AprilNovember) of 2009 and 2010 for two consecutive years at the research farm of the Indian Agricultural Research Institute, New Delhi, to evaluate the effects of summer green manuring crops and zinc $(\mathrm{Zn})$ fertilizer sources on growth and physiological development of Basmati rice (Oryza sativa L.). Summer green manure residue incorporation and zinc fertilization significantly enhanced the growth and physiological development of Basmati rice. Incorporation of Sesbania aculeata (Dhaincha) led to a significant increase in growth parameters, yield attributes and grain and straw yields of succeeding Basmati rice. EDTA-chelated $\mathrm{Zn}(12 \% \mathrm{Zn})$ application significantly improved the growth parameters, yield attributes and grain and straw yields of succeeding Basmati rice over other zinc sources as well as control (no zinc application). Sesbania aculeata (Dhaincha) residue incorporation and EDTA-chelated Zn (12\% Zn) treatments were found to be a better combination with respect to Basmati rice growth and physiological development. The correlation among the various yield attributes and yield indicated that all the yield attributes were highly correlated with yield. Thus, adequate $\mathrm{Zn}$ fertilization along with green manure incorporation can lead to better growth and physiological development for higher productivity of Basmati rice.
\end{abstract}

\section{Introduction}

Rice (Oryza sativa L.) is the most important food for more than $50 \%$ of the world's population, and it is grown on almost 163 million ha of the world's surface. World rice production in 2011 was approximately 722 million tonnes $(\mathrm{mt})$, with more than $90 \%$ produced in Asia (Fertiliser Statistics, 201213). At least 114 countries grow rice. China is the world's largest rice producer, accounting for $28 \%$ of total world production, followed by India $(22 \%)$, Indonesia $(9 \%)$, and Bangladesh $(7 \%)$. India is first in terms of area (44 million ha) and second in production $(157.9 \mathrm{~m} \mathrm{t})$ of paddy, next only to China. However, the average productivity of paddy in India is only $3.59 \mathrm{t} \mathrm{ha}^{-1}$ compared with a world average of $4.43 \mathrm{t}$ ha $^{-1}$, still well below the world average, although increasing marginally (Fertiliser Statistics, 2012-13). Basmati rices are premier rices grown in north-western India and Pakistan. These rice cultivars are preferred for their long and slender kernels which expand to 3-4 times their original length and remain fluffy on cooking.
Paddy (rice) soils are usually deficient in organic matter because of high temperature and moisture, which causes rapid decomposition of organic matter (Mohammed et al., 2005). The application of green manures to soil is considered a good management practice in any agricultural production system because it can increase cropping system sustainability by reducing soil erosion and ameliorating soil physical properties, by increasing soil organic matter and fertility levels (Mandal et al., 2003), by increasing nutrient retention and by reducing global warming potential (Robertson et al., 2000). In northern India some farmers, after harvesting of their wheat crop in the month of April, grow short-duration summer green-manuring crops to add nutrients to the soil by incorporating residue before transplanting Basmati rice. Typically, green manuring crops are grown for a specific-period, and then ploughed and incorporated into the soil. Green manures usually perform multiple functions including soil improvement and soil protection, as well as enhancing soil microbial biomass and enzymatic activity. 
The low availability of zinc ( $\mathrm{Zn})$ in soils is one of the widest ranging abiotic stresses in rice production areas throughout the world, especially in India, Pakistan, China, Australia, Turkey and USA. On average, $50 \%$ of the Indian soils are deficient in $\mathrm{Zn}$, particularly rice soils due to the formation of insoluble Zn hydroxide and its carbonate (Singh and Abrol, 1986 and Rattan and Shukla, 1991). However, Zn was one of the first micronutrients known to be essential for plants, animals, and man (Kabata-Pendias, 2000), and yet, in spite of that knowledge, Zn deficiencies still plague us today (Prasad, 2006; Prasad et al., 2014). Zn plays an important role in different plant metabolism processes like the development of cell walls, respiration, carbohydrates metabolism and gene expression and its regulation (Klug and Rhodes, 1987). Zn deficiency is the most widespread micronutrient disorder among different crops (Dobermann and Fairhurst 2000; Cakmak 2004; Prasad 2009; Prasad 2010; Shivay et al., 2014). The deficiency of this micronutrient frequently occurs in rice which is very sensitive to low Zn supply in submerged rice soils (Fageria, 2001; Karak et al., 2005; Naik and Das, 2008). Crop response to $\mathrm{Zn}$ fertilization varies with the $\mathrm{Zn}$ fertilizer source (Karak et al., 2005). $\mathrm{Zn}$ deficiency is usually corrected through the application of inorganic salts, mainly $\mathrm{ZnSO}_{4} \cdot 7 \mathrm{H}_{2} \mathrm{O}, \mathrm{ZnSO}_{4} \cdot \mathrm{H}_{2} \mathrm{O}$ or $\mathrm{ZnO}$. Other sources are the chelated forms of $\mathrm{Zn}$ such as $\mathrm{Zn}$ EDTA, which supplies substantial amount of $\mathrm{Zn}$ to the plants without interacting with soil components because the central metal ion $\mathrm{Zn}^{2+}$ is surrounded by chelate ligands (Mortvedt, 1979). Further, the application of different $Z n$ fertilizer sources along with green manure crop residue incorporation in soil may exhibit their differential efficiency by interacting with soil components resulting in varying $\mathrm{Zn}$ availability to rice plants, this ultimately affect the growth and development of plants.

Therefore, considering the above-mentioned facts, field experiments were undertaken to study the effect of greenmanuring crops and $\mathrm{Zn}$ fertilizer sources on the growth, yield attributes and yields of Basmati rice under summer green manure-Basmati rice cropping sequence. The results may be helpful in planning an efficient management strategy for improved $\mathrm{Zn}$ nutrition especially for rice crop grown in intensive cropping systems for its better growth and development.

\section{Materials and Methods}

Field experiments were conducted for two consecutive years at the research farm of the Indian Agricultural Research Institute, New Delhi, India during summer-kharif/rainy- seasons of 2009 and 2010 on a sandy clay-loam soil (typic Ustochrept). The experiments in both the years were conducted with a fixed lay-out plan on the same site. The institute farm is located at a latitude of $28^{\circ} 38^{\prime} \mathrm{N}$, at a longitude of $77^{\circ} 10^{\prime} \mathrm{E}$ and at an altitude of 228.6 meters above the mean sea level. The mean annual rainfall of New Delhi is $650 \mathrm{~mm}$ and more than $80 \%$ generally occurs during the south-west monsoon season (July-September) with mean annual evaporation of $850 \mathrm{~mm}$. The soils of experimental field had $135.75 \mathrm{~kg} \mathrm{ha}^{-1}$ alkaline permanganate oxidizable nitrogen $(\mathrm{N})$ (Subbiah and Asija, 1956), $16.04 \mathrm{~kg} \mathrm{ha}^{-1}$ available phosphorus (P) (Olsen et al., 1954), $292.10 \mathrm{~kg} \mathrm{ha}^{-1} 1 \mathrm{~N}$ ammonium acetate exchangeable potassium (K) (Hanway and Heidel, 1952) and $0.53 \%$ organic carbon (C) (Walkley and Black, 1934). The $p \mathrm{H}$ of soil was 7.5 (1:2.5 soil and water ratio) (Prasad et al., 2006) and diethylene triamine penta acetic acid (DTPA)-extractable $\mathrm{Zn}$ (Lindsay and Norvell, 1978) in soil was $0.67 \mathrm{mg} \mathrm{kg}^{-1}$ of soil. The critical level of DTPA-extractable $\mathrm{Zn}$ for rice grown on alluvial soils in the rice-wheat belt of North India varies from $0.38-0.90 \mathrm{mg} \mathrm{kg}^{-1}$ soil (Takkar et al., 1997) and thus, the response of Basmati rice to $\mathrm{Zn}$ application was expected on the experimental field.

The experiment was conducted in a split plot design, keeping three green manuring crops viz. Sesbania aculeata (Dhaincha), Crotalaria juncea (Sunhemp), and Vigna unguiculata (Cowpea) and one summer fallow treatment as main-plot treatments and five $\mathrm{Zn}$ sources viz. $\mathrm{ZnSO}_{4} .7 \mathrm{H}_{2} \mathrm{O}(21 \% \mathrm{Zn})$, $\mathrm{ZnSO}_{4} \cdot \mathrm{H}_{2} \mathrm{O}(33 \% \mathrm{Zn}), \mathrm{ZnO}(82 \% \mathrm{Zn}), \mathrm{ZnSO}_{4} \cdot 7 \mathrm{H}_{2} \mathrm{O}+\mathrm{ZnO}$ $(50 \%+50 \%)$, EDTA-chelated $\mathrm{Zn}(12 \% \mathrm{Zn})$ and a control (no $\mathrm{Zn}$ application) in sub-plots and was replicated thrice. After 42-days the summer green manuring crops were incorporated into the soil before transplanting of rice. The experimental field was disk-ploughed twice, puddled three times with a puddler in standing water and levelled. At final puddling $26 \mathrm{~kg} \mathrm{P} \mathrm{ha}^{-1}$

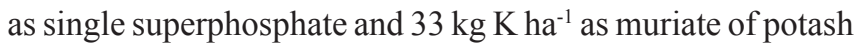
was broadcasted. Nitrogen@ $120 \mathrm{~kg} \mathrm{ha}^{-1}$ as prilled urea was applied into two equal splits, half at the time of transplanting and remaining half at panicle initiation stage (40 DAT). In all the $\mathrm{Zn}$ treatments uniformly $5 \mathrm{~kg} \mathrm{Zn} \mathrm{ha}^{-1}$ was applied to Basmati rice. Three 25-day-old seedlings of Basmati rice variety 'Pusa Basmati 1' was transplanted at $20 \times 10 \mathrm{~cm}$ in the first fortnight of July in both the years of study. Rice crop was grown as per recommended package of practices and was harvested in the second fortnight of October in both the years of experimentation.

Plant height for the Basmati rice was measured at periodic intervals of 30 days till harvest from the base of the plant at ground surface to the tip of the tallest leaf/panicle using a standard meter scale and was expressed in $\mathrm{cm}$. Numbers of tillers were noted by counting from the sampling unit periodically at 30 days interval and was expressed on tillers hill-1 ${ }^{-1}$ basis. Five hills were selected periodically at 30 days interval for recording of total dry matter accumulation by Basmati rice. These plants were then air dried and further dried in a hot air oven at $60 \pm 2^{\circ} \mathrm{C}$ till constant weight was 
obtained. Dry weight was recorded and was expressed on grams hill'-1 basis. Leaf area was measured by separating leaves from the stem, cleaning the leaves with deionized water and drying them with tissue paper. The area of fresh green leaves for each treatment was measured by using a leaf area meter (Model LICOR 3000, USA) and was expressed in $\mathrm{cm}^{2}$ plant $^{-1}$. Leaf area index (LAI) was calculated at the 30,60 and 90 DAT stage using the formula as suggested by Evans (1972). From the ten selected panicles, grains were separated and cleaned. The grain weight per panicle was recorded. The filled and unfilled grains were separated. The number of filled and unfilled (chaffy) grains was counted with the help of a seed counter (Numigral II). The mean value of filled and unfilled (chaffy) grains per panicle was computed and was expressed as numbers of filled and unfilled (chaffy) grains per panicle. From the total number of filled grains and unfilled grains per panicle, the fertility percentage was worked out as:

Fertility $(\%)=($ Number of filled grains per panicle/Total grains per panicle $) \times 100$

The 1,000-filled grains, taken from sampled panicles, were first counted by a seed counter and then weighed to compute the 1,000-grain weight.

Harvesting of Basmati rice was undertaken as soon as it attained the harvest maturity. The harvesting was done with sickles after leaving the border area. Net plots were demarcated at first from the portion of the plot kept for recording grain yield. Plants from the demarcated net plot area were harvested, tied in bundles and taken to the threshing floor for drying and threshing. The harvested plants were dried for 3-4 days to bring down the moisture content to around $14 \%$. After threshing, the seeds were cleaned, sun-dried and their weight was recorded. The yields in $\mathrm{kg} \mathrm{plot}^{-1}$ were converted to $\mathrm{tha}^{-1}$. The weight of the harvested plants after sun drying and before threshing was recorded. Straw yield was obtained by deducting the seed weight from the total weight. The grain and straw yields were expressed in $\mathrm{tha}^{-1}$.

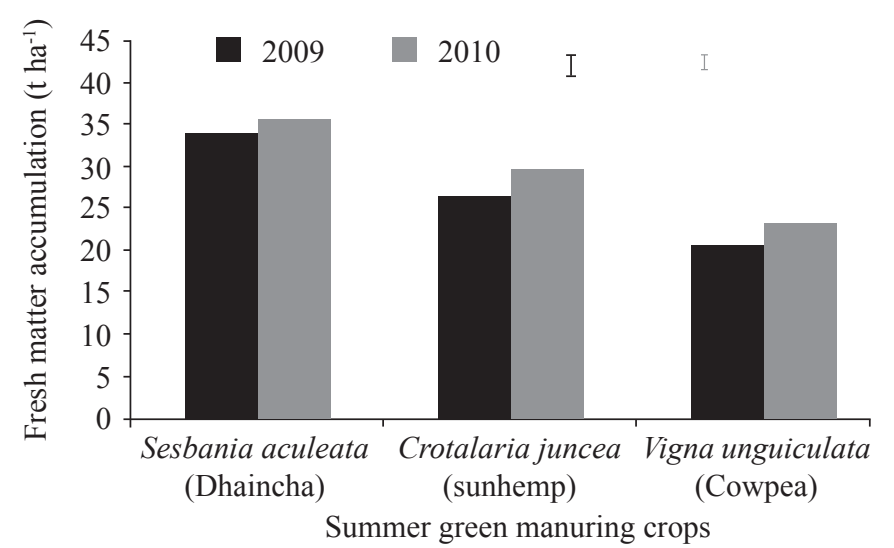

Figure 1: Fresh matter accumulation by summer green manuring crops. The vertical bars represent LSD0.05 values.
All the replicated data obtained from the experiments for consecutive two years of study were statistically analysed using the F-test as per the procedure given by Gomez and Gomez (1984). Least significant difference (LSD) values at $p=0.05$ were used to determine the significance of differences between treatment means. Correlation and regression analysis was done by using SPSS 11.5 package of statistical analysis.

\section{Results and Discussion}

\subsection{Fresh and dry matter accumulation by summer green manuring crops}

Among the summer green manuring crops, dhaincha recorded significantly higher total fresh and dry matter accumulation compared with sunhemp and cowpea in 2009 and 2010 (Figures 1 and 2). Further, sunhemp recorded significantly higher fresh and dry matter over cowpea, but was significantly lower than dhaincha during both the years. The increase in biomass (fresh/dry) accumulation of dhaincha can be due to its fast and determinate growth habit leading to enhanced biomass incorporation/addition and nutrient availability in soil.

\subsection{Basmati rice growth parameters}

In general, all the growth parameters of Basmati rice got significantly influenced by green manure crop residue incorporation and Zn fertilization during 2009 and 2010. Among different $\mathrm{Zn}$ fertilizer sources used, EDTA-chelated $\mathrm{Zn}(12 \% \mathrm{Zn})$ resulted into significantly higher plant height and leaf area index (LAI) (Table 1), numbers of tillers hill ${ }^{-1}$ and dry matter accumulation (Table 2) of Basmati rice at all the growth stages during both the years. Application of $\mathrm{ZnSO}_{4} \cdot 7 \mathrm{H}_{2} \mathrm{O}(21 \%$ $\mathrm{Zn})$ were next best treatment with respect to growth parameters, but was significantly lower than EDTA-chelated Zn (12\% Zn). However, application of $\mathrm{ZnO}(82 \% \mathrm{Zn})$ was least effective with respect to growth parameters, although it significantly increased growth parameters compared to the control (no $\mathrm{Zn}$ application). The lowest values of growth parameters were

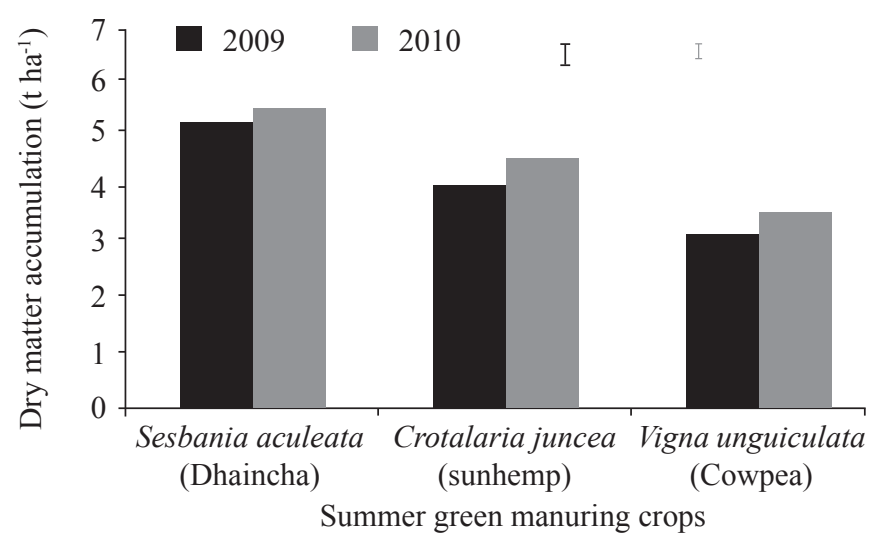

Figure 2: Dry matter accumulation by summer green manuring crops. The vertical bars represent LSD0.05 values. 
recorded in control (no $\mathrm{Zn}$ application) followed by $\mathrm{ZnO}(82 \%$

$\mathrm{Zn}$ ) application. In both years of the study, the tallest plants were recorded with EDTA-chelated Zn (12\% Zn) and shortest with control (no Zn application). There was a 93.6 and $100 \%$

Table 1: Effect of summer green manuring crops and Zn fertilizer sources on the plant height and leaf area index (LAI) of Basmati rice

\begin{tabular}{|c|c|c|c|c|c|c|c|c|c|c|c|c|c|c|}
\hline \multirow[t]{3}{*}{ Treatment } & \multicolumn{8}{|c|}{ Plant height $(\mathrm{cm})$} & \multicolumn{6}{|c|}{ Leaf area index (LAI) } \\
\hline & \multicolumn{2}{|c|}{30 DAT $^{*}$} & \multicolumn{2}{|c|}{60 DAT } & \multicolumn{2}{|c|}{90 DAT } & \multicolumn{2}{|c|}{ Harvest } & \multicolumn{2}{|c|}{30 DAT } & \multicolumn{2}{|c|}{60 DAT } & \multicolumn{2}{|c|}{90 DAT } \\
\hline & 2009 & 2010 & 2009 & 2010 & 2009 & 2010 & 2009 & 2010 & 2009 & 2010 & 2009 & 2010 & 2009 & 2010 \\
\hline \multicolumn{15}{|l|}{ Summer-green manuring crops } \\
\hline Sesbania aculeata (Dhaincha) & 65.0 & 67.5 & 86.0 & 91.9 & 110.9 & 115.0 & 118.6 & 120.8 & 3.2 & 3.3 & 5.9 & 6.1 & 4.7 & 4.8 \\
\hline Crotalaria juncea (Sunhemp) & 63.4 & 65.7 & 83.9 & 89.3 & 106.8 & 109.0 & 115.8 & 117.2 & 2.8 & 2.9 & 5.7 & 5.9 & 4.5 & 4.6 \\
\hline Vigna unguiculata (Cowpea) & 60.9 & 63.5 & 80.6 & 85.7 & 103.0 & 106.5 & 112.8 & 114.1 & 2.5 & 2.6 & 5.4 & 5.6 & 4.3 & 4.4 \\
\hline Summer fallow & 58.4 & 59.7 & 77.3 & 81.3 & 99.8 & 101.2 & 109.6 & 110.1 & 2.3 & 2.4 & 5.2 & 5.4 & 4.1 & 4.3 \\
\hline $\operatorname{SEm} \pm$ & 0.63 & 1.11 & 0.81 & 1.47 & 1.13 & 1.16 & 0.87 & 0.93 & 0.03 & 0.03 & 0.04 & 0.07 & 0.04 & 0.04 \\
\hline $\operatorname{LSD}(p=0.05)$ & 2.19 & 3.84 & 2.81 & 5.09 & 3.90 & 4.00 & 3.02 & 3.22 & 0.11 & 0.12 & 0.14 & 0.25 & 0.14 & 0.13 \\
\hline \multicolumn{15}{|l|}{ Zinc sources } \\
\hline Control & 58.0 & 59.8 & 76.4 & 80.2 & 97.7 & 100.5 & 109.4 & 108.9 & 2.2 & 2.3 & 5.1 & 5.3 & 4.0 & 4.2 \\
\hline $\mathrm{ZnSO}_{4} \cdot 7 \mathrm{H}_{2} \mathrm{O}(21 \% \mathrm{Zn})$ & 64.5 & 66.1 & 84.7 & 91.0 & 109.5 & 112.2 & 116.8 & 119.9 & 3.0 & 3.1 & 5.8 & 6.1 & 4.6 & 4.7 \\
\hline $\mathrm{ZnSO}_{4} \cdot \mathrm{H}_{2} \mathrm{O}(33 \% \mathrm{Zn})$ & 62.4 & 64.4 & 82.8 & 87.9 & 106.1 & 109.1 & 114.5 & 115.8 & 2.8 & 2.9 & 5.6 & 5.8 & 4.4 & 4.6 \\
\hline $\mathrm{ZnO}(82 \% \mathrm{Zn})$ & 59.7 & 61.5 & 79.2 & 82.5 & 100.8 & 103.6 & 110.9 & 111.3 & 2.4 & 2.5 & 5.3 & 5.4 & 4.2 & 4.3 \\
\hline $\mathrm{ZnSO}_{4} \cdot 7 \mathrm{H}_{2} \mathrm{O}+\mathrm{ZnO}(50 \%+50 \%)$ & 60.8 & 63.3 & 81.1 & 85.3 & 103.6 & 105.6 & 113.4 & 113.7 & 2.6 & 2.7 & 5.4 & 5.6 & 4.3 & 4.4 \\
\hline EDTA-chelated Zn (12\% Zn) & 66.2 & 69.4 & 87.4 & 95.4 & 113.1 & 116.7 & 120.3 & 123.6 & 3.1 & 3.4 & 6.1 & 6.3 & 4.8 & 5.0 \\
\hline $\operatorname{SEm} \pm$ & 0.43 & 0.42 & 0.55 & 0.80 & 0.81 & 0.77 & 0.52 & 0.81 & 0.04 & 0.04 & 0.04 & 0.05 & 0.03 & 0.03 \\
\hline $\operatorname{LSD}(p=0.05)$ & 1.23 & 1.20 & 1.57 & 2.30 & 2.31 & 2.21 & 1.47 & 2.30 & 0.11 & 0.12 & 0.13 & 0.14 & 0.09 & 0.10 \\
\hline
\end{tabular}

DAT*: Days after transplanting

Table 2: Effect of summer green manuring crops and $\mathrm{Zn}$ fertilizer sources on the number of tillers hill ${ }^{-1}$ and dry matter accumulation of Basmati rice

\begin{tabular}{|c|c|c|c|c|c|c|c|c|c|c|c|c|c|c|}
\hline & \multicolumn{6}{|c|}{ Tillers hill $^{-1}$} & \multirow{2}{*}{\multicolumn{2}{|c|}{$\begin{array}{c}\begin{array}{c}\text { Effective } \\
\text { tillers hill }^{-1}\end{array} \\
\text { Harvest }\end{array}$}} & \multicolumn{6}{|c|}{$\begin{array}{l}\text { Dry matter accumulation } \\
\qquad\left(\mathrm{g} \mathrm{hill}{ }^{-1}\right)\end{array}$} \\
\hline & \multicolumn{2}{|c|}{30 DAT $^{*}$} & \multicolumn{2}{|c|}{60 DAT } & \multicolumn{2}{|c|}{90 DAT } & & & \multicolumn{2}{|c|}{30 DAT } & \multicolumn{2}{|c|}{60 DAT } & \multicolumn{2}{|c|}{90 DAT } \\
\hline & 2009 & 2010 & 2009 & 2010 & 2009 & 2010 & 2009 & 2010 & 2009 & 2010 & 2009 & 2010 & 2009 & 2010 \\
\hline \multicolumn{15}{|l|}{ Summer-green manuring crops } \\
\hline$\overline{\text { Sesbania aculeata (Dhaincha) }}$ & 19.0 & 21.7 & 22.0 & 25.6 & 19.3 & 21.6 & 16.6 & 18.6 & 7.9 & 9.5 & 15.7 & 17.6 & 41.0 & 45.3 \\
\hline Crotalaria juncea (Sunhemp) & 17.3 & 19.3 & 19.3 & 22.8 & 17.2 & 19.4 & 14.7 & 16.9 & 7.3 & 8.3 & 14.3 & 15.6 & 38.3 & 41.4 \\
\hline Vigna unguiculata (Cowpea) & 15.7 & 16.4 & 17.6 & 19.8 & 15.1 & 16 & 12.9 & & 6.7 & 7.7 & 12.5 & 13.5 & 35.9 & 38.5 \\
\hline Summe & 14.2 & 15.1 & 15.9 & 17.4 & 13.6 & 14.3 & 11.1 & 12.6 & 6.3 & 6.9 & 11.2 & 11.8 & 32.6 & 35.6 \\
\hline $\operatorname{SEm} \pm$ & 0.46 & 0.59 & 0.62 & 0.81 & 0.60 & 0.80 & 0.63 & & 0.09 & 0.15 & 0.41 & 0.66 & 0.76 & 0.73 \\
\hline $\operatorname{LSD}(p=0.05)$ & 1.59 & 2.03 & 2.13 & 2.79 & 2.06 & 2.75 & 2.17 & 2.62 & 0.32 & 0.51 & 1.42 & 2.27 & 2.63 & 2.51 \\
\hline \multicolumn{15}{|l|}{ Zinc sources } \\
\hline Control & 12.0 & 12.9 & 13.9 & & & & 9.4 & & 5.8 & 6.6 & 10.7 & 10.6 & 31.8 & 32.9 \\
\hline $\mathrm{ZnSO}_{4} \cdot 7 \mathrm{H}_{2} \mathrm{O}(21 \% \mathrm{Zn})$ & 19.0 & 21.0 & 21.7 & 24.8 & 19.2 & 21.2 & 16.3 & 18.7 & 7.9 & 8.7 & 14.8 & 16.8 & 39.8 & 43.6 \\
\hline $\mathrm{ZnSO}_{4} \cdot \mathrm{H}_{2} \mathrm{O}(33 \% \mathrm{Zn})$ & 17.4 & 18.7 & 19.6 & 22.2 & 17.3 & 18.2 & 14.7 & 16.2 & 7.2 & 8.1 & 13.6 & 15.1 & 37.0 & 40.7 \\
\hline $\mathrm{ZnO}(82 \% \mathrm{Zn})$ & 14.2 & 15.2 & 16.1 & 17.7 & 13.6 & 14.6 & 11.5 & 12.3 & 6.3 & 7.2 & 11.8 & 12.3 & 34.1 & 36.5 \\
\hline $\mathrm{ZnSO}_{4} \cdot 7 \mathrm{H}_{2} \mathrm{O}+\mathrm{ZnO}(50 \%+50 \%)$ & 15.9 & 17.3 & 17.4 & 20.2 & 15.0 & 16.8 & 12.9 & 14.6 & 6.8 & 7.6 & 12.7 & 13.6 & 35.5 & 38.6 \\
\hline EDTA-chelated Zn (12\% Zn) & 20.7 & 23.7 & 23.5 & 28.3 & 20.8 & 23.8 & 18.2 & 21.4 & 8.4 & 10.3 & 16.8 & 19.3 & 43.4 & 49.0 \\
\hline $\mathrm{SEm} \pm$ & 0.44 & 0.52 & 0.46 & 0.63 & 0.50 & 0.58 & 0.50 & 0.61 & 0.12 & 0.13 & 0.28 & 0.49 & 0.49 & 0.75 \\
\hline $\operatorname{LSD}(p=0.05)$ & 1.25 & 1.49 & 1.31 & 1.81 & 1.42 & 1.66 & 1.44 & 1.74 & 0.33 & 0.37 & 0.80 & 1.39 & 1.39 & 2.15 \\
\hline
\end{tabular}

DAT*: Days after transplanting 
increase in the number of effective tillers hill ${ }^{-1}$ and 36.7 and $48.9 \%$ increase in dry matter (at 90 DAT) of Basmati rice over control (no Zn application) in 2009 and 2010, respectively. A similar trend was observed with respect to LAI. The LAI at 60 DAT was highest (varied from 5.1 to 6.3) compared with 30 and 90 DAT. This might be due to the fact that, at this stage, the leaves are fully functional and expanded compared with 30 and 90 DAT. Among the different summer green manure crops, incorporation of dhaincha resulted in significantly higher values of growth parameters of Basmati rice over sunhemp, cowpea and summer fallow. The lowest values of growth parameters at all growth stages were observed when Basmati rice was grown after summer fallow treatment. Incorporation of dhaincha residue resulted into 25.7 and $27.2 \%$ increase in dry matter of Basmati rice over summer fallow at 90 DAT in 2009 and 2010, respectively. But, the incorporation of cowpea resulted into the values of dry matter which remained at par with summer fallow at $60 \mathrm{DAT}$, however was significantly higher at harvest.

All the growth parameters, viz. plant height, dry matter accumulation, number of tillers and LAI of Basmati rice, were significantly influenced by the incorporation of summer green-manuring crops' residues and $\mathrm{Zn}$ fertilization. This might be due to higher nutrient availability and better physicochemical soil properties under green manure incorporated plots and because of higher $\mathrm{Zn}$ availability to the rice plants from applied zinc fertilizers. This could be attributed to the higher supply of $\mathrm{N}$ and other micronutrient cations through the incorporation of legumes into soil (Bisht et al., 2006). In addition to $\mathrm{N}$ contribution, the biomass of these summer green manures also recycled considerable quantities of $\mathrm{P}, \mathrm{K}$ and other nutrients; and thus might have improved fertility build-up, physical and biological properties of the soil (Sharma and Prasad, 1999; Jensen and Hauggaard-Nielsen 2003; Kirkegaard et al., 2008). Similar findings were also reported by Pooniya and Shivay (2012). The increased availability of $\mathrm{Fe}$ and other micronutrients in soil with regular summer green manuring crops every year before transplanting of rice was responsible for higher growth and development of rice plants in the green manuring plot compared with the non-green manuring plot (Nayyar and Chhibba, 2000). The increase in the growth parameters of rice with $\mathrm{Zn}$ fertilization may also be due to higher $\mathrm{Zn}$ availability to plants in $\mathrm{Zn}$ applied plots compared to control (no $\mathrm{Zn}$ application). Increase in plant height with $\mathrm{Zn}$ application could be due to higher synthesis of auxins as $\mathrm{Zn}$ is required for its normal production (Alloway, 2008). The relatively higher maintenance of available $\mathrm{Zn}$ in soil due to applied EDTA-chelated $\mathrm{Zn}(12 \% \mathrm{Zn})$ may be attributed from the very little or no interaction between soil components preventing various harmful reactions occurring in soil as compared to soil treated with other $\mathrm{Zn}$ sources, which enhances greater fixation, adsorption etc, resulting from the greater interaction between soil components. Ortiz and Garcia (1998) also reported that the chelated- $\mathrm{Zn}$ is fixed less in soil than the sulphate source. Srivastava et al. (1999) also studied the comparative efficiency of different sources of $\mathrm{Zn}$ for low land rice production and reported that out of various sources, the chelated-Zn (Zn-EDTA) was the most efficient sources of $\mathrm{Zn}$ for low land rice production. The performance of $\mathrm{Zn}$ sources in our studies was in the order; EDTA-chelated $\mathrm{Zn}(12 \% \mathrm{Zn})>\mathrm{ZnSO}_{4} .7 \mathrm{H}_{2} \mathrm{O}(21 \% \mathrm{Zn})>\mathrm{ZnSO}_{4}$. $\mathrm{H}_{2} \mathrm{O}(33 \% \mathrm{Zn})>\mathrm{ZnSO}_{4} \cdot 7 \mathrm{H}_{2} \mathrm{O}+\mathrm{ZnO}(50 \%+50 \%)>\mathrm{ZnO}(82 \%$ $\mathrm{Zn})$. The results obtained are in accordance with Karak et al. (2005) and Naik and Das (2008). The better performance of $\mathrm{ZnSO}_{4} \cdot 7 \mathrm{H}_{2} \mathrm{O}$ and $\mathrm{ZnSO}_{4} \cdot \mathrm{H}_{2} \mathrm{O}(33 \% \mathrm{Zn})$ over $\mathrm{ZnO}$ is due to its water solubility. Water solubility of $\mathrm{Zn}$ sources is considered an important criterion for $\mathrm{Zn}$ availability (Slaton et al., 2005a and Slaton et al., 2005b). The lower values of growth parameters of Basmati rice reported under control (no $\mathrm{Zn}$ application) could be because, when soils are submerged, the availability of $\mathrm{Zn}$ to plants decreases. In submerged condition, there is a formation of large amounts of very insoluble $\mathrm{Zn}$ compounds, which results in lower Zn uptake. Brar and Sekhon (1976), Mandal et al. (1993) and Singh et al. (1999) also reported the decrease in the $\mathrm{Zn}$ availability to rice plants under submerged conditions, resulting into decrease in growth and development of plants.

\subsection{Yield attributes of Basmati rice}

The incorporation of summer green-manuring crop residue and various $\mathrm{Zn}$ fertilization treatments significantly influenced the panicle length and panicle weight (Table 4), filled, unfilled

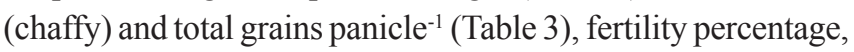
grain weight panicle ${ }^{-1}$ and 1,000-grain weight (Table 3 ) of Basmati rice during both the years. The number of unfilled (chaffy) grains got significantly reduced with summer green manure residue incorporation and with $\mathrm{Zn}$ fertilization (Table 3 ). The significantly higher values of the yield attributes were recorded when Basmati rice was grown after dhaincha incorporation compared with sunhemp, cowpea and summer fallow treatments. The highest and lowest values of all these yield attributes were recorded with dhaincha and summer fallow treatments, respectively. Fertility percentage was significantly influenced by both the green manure residue incorporation as well as $\mathrm{Zn}$ fertilization. Dhaincha residue incorporation and EDTA-chelated Zn (12\% Zn) were statistically superior over all other green manure and $\mathrm{Zn}$ fertilization treatments including controls (summer fallow and no $\mathrm{Zn}$ application), respectively in both the years. 
Among the $\mathrm{Zn}$ fertilization treatments, application of EDTAchelated $\mathrm{Zn}(12 \% \mathrm{Zn})$ resulted into statistically higher values of yield attributes compared with all $\mathrm{Zn}$ fertilizer sources and control (no $\mathrm{Zn}$ application). $\mathrm{ZnSO}_{4}$. Application of $7 \mathrm{H}_{2} \mathrm{O}$ $(21 \% \mathrm{Zn})$ was second best treatment with respect to all these yield attributes after EDTA-chelated $\mathrm{Zn}(12 \% \mathrm{Zn})$, but was statistically inferior to it. The lowest values of all these yield attributes were observed with no $\mathrm{Zn}$ application (control).

\subsection{Grain and straw yields of Basmati rice}

In general, the grain and straw yields were higher during the second year of experimentation (Table 4). The yields of

\begin{tabular}{|c|c|c|c|c|c|c|c|c|c|c|c|c|}
\hline \multirow[t]{2}{*}{ Treatment } & \multicolumn{2}{|c|}{$\begin{array}{l}\text { Filled grains } \\
\text { panicle }^{-1} \\
\text { (A) }\end{array}$} & \multicolumn{2}{|c|}{$\begin{array}{c}\text { Unfilled } \\
\text { (Chaffy) grains } \\
\text { panicle }^{-1}(\mathrm{~B})\end{array}$} & \multicolumn{2}{|c|}{$\begin{array}{l}\text { Total grains } \\
\text { panicle }^{-1} \\
(\mathrm{~A}+\mathrm{B})\end{array}$} & \multicolumn{2}{|c|}{$\begin{array}{c}\text { Fertility } \\
\text { percentage } \\
(\%)\end{array}$} & \multicolumn{2}{|c|}{$\begin{array}{l}\text { Grain weight } \\
\text { (g) panicle } \text { pl }^{-1}\end{array}$} & \multicolumn{2}{|c|}{$\begin{array}{c}\text { 1,000-grain } \\
\text { weight } \\
\text { (g) }\end{array}$} \\
\hline & 2009 & 2010 & 2009 & 2010 & 2009 & 2010 & 2009 & 2010 & 2009 & 2010 & 2009 & 2010 \\
\hline \multicolumn{13}{|l|}{ Summer-green manuring crops } \\
\hline Sesbania aculeata (Dhaincha) & 86.9 & 87.6 & 34.8 & 35.1 & 121.7 & 122.9 & 71.2 & 71.3 & 2.48 & 2.63 & 25.37 & 25.88 \\
\hline Crotalaria juncea (Sunhemp) & 81.9 & 83.2 & 36.1 & 36.2 & 118.1 & 119.4 & 69.1 & 69.7 & 2.34 & 2.47 & 24.95 & 25.13 \\
\hline Vigna unguiculata (Cowpea) & 75.8 & 76.6 & 37.2 & 38.0 & 113.4 & 114.6 & 66.5 & 66.5 & 2.17 & 2.33 & 24.25 & 24.63 \\
\hline Summer fallow & 68.6 & 70.7 & 39.8 & 38.3 & 108.4 & 109.0 & 62.9 & 64.4 & 2.02 & 2.14 & 23.47 & 24.01 \\
\hline $\mathrm{SEm} \pm$ & 1.39 & 1.60 & 0.42 & 0.41 & 1.03 & 1.34 & 0.69 & 0.71 & 0.031 & 0.038 & 0.132 & 0.162 \\
\hline $\operatorname{LSD}(p=0.05)$ & 4.78 & 5.52 & 1.44 & 1.42 & 3.57 & 4.61 & 2.39 & 2.47 & 0.108 & 0.130 & 0.456 & 0.558 \\
\hline \multicolumn{13}{|l|}{ Zinc sources } \\
\hline Control & 62.4 & 63.7 & 42.7 & 42.1 & 105.1 & 105.8 & 59.2 & 60.1 & 1.89 & 1.93 & 22.54 & 22.69 \\
\hline $\mathrm{ZnSO}_{4} .7 \mathrm{H}_{2} \mathrm{O}(21 \% \mathrm{Zn})$ & 86.8 & 87.4 & 34.1 & 34.9 & 120.9 & 122.3 & 71.7 & 71.4 & 2.48 & 2.62 & 25.71 & 26.14 \\
\hline $\mathrm{ZnSO}_{4} \cdot \mathrm{H}_{2} \mathrm{O}(33 \% \mathrm{Zn})$ & 80.7 & 81.9 & 36.3 & 36.2 & 117.2 & 118.1 & 68.7 & 69.1 & 2.28 & 2.43 & 24.82 & 25.21 \\
\hline $\mathrm{ZnO}(82 \% \mathrm{Zn})$ & 71.3 & 72.5 & 38.8 & 38.4 & 110.1 & 110.9 & 64.5 & 65.2 & 2.06 & 2.17 & 23.33 & 23.96 \\
\hline $\mathrm{ZnSO}_{4} \cdot 7 \mathrm{H}_{2} \mathrm{O}+\mathrm{ZnO}(50 \%+50 \%)$ & 75.6 & 77.6 & 37.8 & 37.2 & 113.8 & 114.8 & 66.2 & 67.4 & 2.18 & 2.31 & 24.07 & 24.69 \\
\hline EDTA-chelated Zn (12\% Zn) & 93.0 & 93.8 & 32.3 & 32.6 & 125.4 & 126.8 & 74.1 & 74.7 & 2.63 & 2.88 & 26.59 & 26.77 \\
\hline $\mathrm{SEm} \pm$ & 0.94 & 0.99 & 0.22 & 0.25 & 0.82 & 1.00 & 0.41 & 0.41 & 0.025 & 0.034 & 0.153 & 0.148 \\
\hline $\operatorname{LSD}(p=0.05)$ & 2.68 & 2.84 & 0.62 & 0.70 & 2.35 & 2.85 & 1.16 & 1.18 & 0.070 & 0.098 & 0.438 & 0.422 \\
\hline
\end{tabular}

Table 4: Effect of summer green manuring crops and $\mathrm{Zn}$ fertilizer sources on the yield attributes and grain and straw yields of Basmati rice

\begin{tabular}{|c|c|c|c|c|c|c|c|c|}
\hline \multirow[t]{2}{*}{ Treatment } & \multicolumn{2}{|c|}{ Panicle length $(\mathrm{cm})$} & \multicolumn{2}{|c|}{ Panicle weight $(\mathrm{g})$} & \multicolumn{2}{|c|}{ Grain yield $\left(\mathrm{t} \mathrm{ha}^{-1}\right)$} & \multicolumn{2}{|c|}{ Straw yield $\left(\mathrm{t} \mathrm{ha}^{-1}\right)$} \\
\hline & 2009 & 2010 & 2009 & 2010 & 2009 & 2010 & 2009 & 2010 \\
\hline \multicolumn{9}{|l|}{ Summer-green manuring crops } \\
\hline Sesbania aculeata (Dhaincha) & 28.8 & 29.5 & 3.00 & 3.07 & 4.89 & 5.56 & 9.04 & 10.21 \\
\hline Crotalaria juncea (Sunhemp) & 27.3 & 28.0 & 2.82 & 2.89 & 4.74 & 5.34 & 8.83 & 10.02 \\
\hline Vigna unguiculata (Cowpea) & 26.0 & 26.4 & 2.63 & 2.74 & 4.58 & 5.12 & 8.64 & 9.82 \\
\hline Summer fallow & 25.1 & 24.6 & 2.38 & 2.50 & 4.30 & 4.86 & 8.36 & 9.63 \\
\hline $\mathrm{SEm} \pm$ & 0.36 & 0.62 & 0.025 & 0.029 & 0.041 & 0.026 & 0.039 & 0.031 \\
\hline $\operatorname{LSD}(p=0.05)$ & 1.25 & 2.16 & 0.087 & 0.100 & 0.141 & 0.091 & 0.135 & 0.105 \\
\hline \multicolumn{9}{|l|}{ Zinc sources } \\
\hline Control & 24.2 & 23.1 & 2.34 & 2.40 & 4.09 & 4.75 & 8.13 & 9.39 \\
\hline $\mathrm{ZnSO}_{4} \cdot 7 \mathrm{H}_{2} \mathrm{O}(21 \% \mathrm{Zn})$ & 28.3 & 29.3 & 2.93 & 3.05 & 4.92 & 5.41 & 9.04 & 10.18 \\
\hline $\mathrm{ZnSO}_{4} \cdot \mathrm{H}_{2} \mathrm{O}(33 \% \mathrm{Zn})$ & 27.2 & 27.4 & 2.77 & 2.85 & 4.74 & 5.27 & 8.81 & 10.02 \\
\hline $\mathrm{ZnO}(82 \% \mathrm{Zn})$ & 25.3 & 25.3 & 2.50 & 2.57 & 4.32 & 4.98 & 8.40 & 9.61 \\
\hline $\mathrm{ZnSO}_{4} \cdot 7 \mathrm{H}_{2} \mathrm{O}+\mathrm{ZnO}(50 \%+50 \%)$ & 26.2 & 26.8 & 2.61 & 2.72 & 4.54 & 5.15 & 8.61 & 9.85 \\
\hline EDTA-chelated Zn (12\% Zn) & 29.7 & 30.7 & 3.09 & 3.19 & 5.15 & 5.76 & 9.30 & 10.48 \\
\hline $\mathrm{SEm} \pm$ & 0.24 & 0.43 & 0.028 & 0.032 & 0.043 & 0.027 & 0.046 & 0.032 \\
\hline $\operatorname{LSD}(p=0.05)$ & 0.69 & 1.24 & 0.079 & 0.090 & 0.123 & 0.077 & 0.131 & 0.090 \\
\hline
\end{tabular}


Basmati rice were significantly influenced by incorporation of summer green manuring crop residue and $\mathrm{Zn}$ sources. The significantly higher grain and straw yields of Basmati rice were recorded when it was grown after dhaincha incorporation compared with sunhemp, cowpea and summer fallow treatments. With the incorporation dhaincha, sunhemp and cowpea, about 5.46 and 5.77, 4.16 and 4.76, 3.00 and $3.77 \mathrm{t} \mathrm{ha}^{-1}$ of dry biomass was added to the soil during first and second year of experimentation, respectively (Figure 2). Dhaincha supplied significantly higher amount of readily decomposable organic materials, which improved soil organic matter and nutrient status. It leads to recycling of nutrients into the soil and increased availability of nutrients and thus improved the yield attributes and yields of Basmati rice.

Among the $\mathrm{Zn}$ fertilization treatments, application of EDTAchelated $\mathrm{Zn}(12 \% \mathrm{Zn})$ resulted into statistically higher values of grain $\left(5.15\right.$ and $\left.5.76 \mathrm{t} \mathrm{ha}^{-1}\right)$ and straw yields (9.30 and $10.48 \mathrm{t} \mathrm{ha}^{-1}$ ) compared with all other $\mathrm{Zn}$ fertilizer sources and control (no $\mathrm{Zn}$ application), respectively during 2009 and 2010. Application of $\mathrm{ZnSO}_{4} \cdot 7 \mathrm{H}_{2} \mathrm{O}(21 \% \mathrm{Zn})$ was second best treatment with respect to grain (4.92 and $\left.5.41 \mathrm{t} \mathrm{ha}^{-1}\right)$ and straw yields (9.04 and $\left.10.18 \mathrm{tha}^{-1}\right)$ after EDTA-chelated $\mathrm{Zn}(12 \% \mathrm{Zn})$, but was statistically inferior to it. The lowest values of grain, straw and biological yields were recorded with control (no $\mathrm{Zn}$ application). The performance of $\mathrm{Zn}$ sources in terms of yields of Basmati rice was in the order; EDTAchelated $\mathrm{Zn}(12 \% \mathrm{Zn})>\mathrm{ZnSO}_{4} \cdot 7 \mathrm{H}_{2} \mathrm{O}(21 \% \mathrm{Zn})>\mathrm{ZnSO}_{4} \cdot \mathrm{H}_{2} \mathrm{O}$ $(33 \% \mathrm{Zn})>\mathrm{ZnSO}_{4} \cdot 7 \mathrm{H}_{2} \mathrm{O}+\mathrm{ZnO}(50 \%+50 \%)>\mathrm{ZnO}(82 \% \mathrm{Zn})$. Percent increase in grain and straw yields with EDTA-chelated $\mathrm{Zn}(12 \% \mathrm{Zn})$ application over control (no Zn application) was $25.91,21.26 \%$ and $14.39,11.60 \%$, respectively during
2009 and 2010. The increase in grain and straw yields due to incorporation of summer green-manuring crops and $\mathrm{Zn}$ fertilization can be explained on the basis of increase in the yield attributes, namely panicle length, panicle weight, number of grains per panicle and 1,000 grain weight of Basmati rice.

Increase in yield attributes and yields of Basmati rice with $\mathrm{Zn}$ application might be due to higher $\mathrm{Zn}$ uptake with $\mathrm{Zn}$ fertilization, resulting into higher biomass production (Shivay et al., 2008 and Pooniya et al., 2012) and photosynthates translocation to reproductive parts (Ozkutlu et al., 2006; Alloway, 2008). The increase in yield attributes and yields of Basmati rice with application of EDTA-chelated Zn (12\% $\mathrm{Zn}$ ) might be due to the relatively greater amount of $\mathrm{Zn}$ uptake compared with other $\mathrm{Zn}$ sources. These results are in agreement with the findings of Karak et al. (2005) who reported that chelated $\mathrm{Zn}$ was the most efficient source of $\mathrm{Zn}$ for lowland rice production. Further, the incorporation of green manuring crops before transplanting of Basmati rice improves the organic matter content in soil. The applied $\mathrm{Zn}$ might have been complexed with the humic substances present in soil due to organic matter addition and there might have been lesser $\mathrm{Zn}$ fixation by the formation of insoluble $\mathrm{Zn}$ complexes. Thus resulting into increase in the availability of soil applied $\mathrm{Zn}$ to rice plants. Improvement in the nutrient use efficiency of the applied fertilizers by transplanted rice after green manure incorporation was also reported by Yadvinder-Singh et al. (1991). The correlation among the various yield attributes and yield were estimated (Table 5), which indicated that all the yield attributes were highly correlated with yield.

\begin{tabular}{|c|c|c|c|c|c|c|c|c|c|c|c|c|c|c|c|c|}
\hline & \multicolumn{2}{|c|}{ Yield } & \multicolumn{2}{|c|}{$\begin{array}{l}\text { Effective } \\
\text { tillers }\end{array}$} & \multicolumn{2}{|c|}{$\begin{array}{l}\text { Panicle } \\
\text { length }\end{array}$} & \multicolumn{2}{|c|}{$\begin{array}{l}\text { Panicle } \\
\text { weight }\end{array}$} & \multicolumn{2}{|c|}{$\begin{array}{l}\text { Number } \\
\text { of grains } \\
\text { panicle }^{-1}\end{array}$} & \multicolumn{2}{|c|}{$\begin{array}{c}\text { Grain } \\
\text { weight } \\
\text { panicle }^{-1}\end{array}$} & \multicolumn{2}{|c|}{$\begin{array}{c}\text { 1,000-grain } \\
\text { weight }\end{array}$} & \multicolumn{2}{|c|}{$\begin{array}{l}\text { Number of } \\
\text { filled grains } \\
\text { panicle }^{-1}\end{array}$} \\
\hline & 2009 & 2010 & 2009 & 2010 & 2009 & 2010 & 2009 & 2010 & 2009 & 2010 & 2009 & 2010 & 2009 & 2010 & 2009 & 2010 \\
\hline Yield & $1.00^{* *}$ & $1.00^{* *}$ & $0.98^{* *}$ & $0.97^{* *}$ & $0.97^{* *}$ & $0.98^{* *}$ & $0.96^{* *}$ & $0.97^{* *}$ & $0.98^{* *}$ & $0.98^{* *}$ & $0.97^{* *}$ & $0.97^{* *}$ & $0.98^{* *}$ & $0.94^{* *}$ & $0.98^{* *}$ & $0.98^{* *}$ \\
\hline Effective tillers & & & $1.00^{* *}$ & $1.00^{* *}$ & $0.98^{* *}$ & $0.96^{* *}$ & $0.97^{* *}$ & $0.97^{* *}$ & $0.99^{* *}$ & $0.97^{* *}$ & $0.99^{* *}$ & $0.98^{* *}$ & $0.97^{* *}$ & $0.96^{* *}$ & $0.99^{* *}$ & $0.97^{* *}$ \\
\hline Panicle length & & & & & $1.00^{* *}$ & $1.00^{* *}$ & $0.98^{* *}$ & $0.99^{* *}$ & $0.98^{* *}$ & $0.99^{* *}$ & $0.98^{* *}$ & $0.97^{* *}$ & $0.97^{* *}$ & $0.97^{* *}$ & $0.98^{* *}$ & $0.99^{* *}$ \\
\hline Panicle weight & & & & & & & $1.00^{* *}$ & $1.00^{* *}$ & $0.98^{* *}$ & $0.98^{* *}$ & $0.97^{* *}$ & $0.98^{* *}$ & $0.96^{* *}$ & $0.97^{* *}$ & $0.98^{* *}$ & $0.98^{* *}$ \\
\hline $\begin{array}{l}\text { Number of } \\
\text { grains panicle }^{-1}\end{array}$ & & & & & & & & & $1.00^{* *}$ & $1.00^{* *}$ & $0.98^{* *}$ & $0.98^{* *}$ & $0.98^{* *}$ & $0.98^{* *}$ & $1.00^{* *}$ & $1.00^{* *}$ \\
\hline $\begin{array}{l}\text { Grain weight } \\
\text { panicle }^{-1}\end{array}$ & & & & & & & & & & & $1.00^{* *}$ & $1.00^{* *}$ & $0.97^{* *}$ & $0.98^{* *}$ & $0.98^{* *}$ & $0.98^{* *}$ \\
\hline $\begin{array}{l}\text { 1,000-grain } \\
\text { weight }\end{array}$ & & & & & & & & & & & & & $1.00^{* *}$ & $1.00^{* *}$ & $0.98^{* *}$ & $0.98^{* *}$ \\
\hline $\begin{array}{l}\text { Number of filled } \\
\text { grains panicle }^{-1}\end{array}$ & & & & & & & & & & & & & & & $1.00^{* *}$ & $1.00^{* *}$ \\
\hline
\end{tabular}




\section{Conclusion}

Results showed that the incorporation of dhaincha green manure before transplanting of Basmati rice and application of EDTA-Chelated $\mathrm{Zn}(12 \% \mathrm{Zn})$ improved the growth and physiological development of Basmati rice compared to rest of green manuring crops and $\mathrm{Zn}$ fertilizer sources. Dhaincha and EDTA-Chelated $\mathrm{Zn}(12 \% \mathrm{Zn})$ were found to be the best to obtain higher grain and straw yields of Basmati rice and thus enhanced its productivity. Adequate $\mathrm{Zn}$ fertilization of Basmati rice along with incorporation of summer green manure crops can thus lead to better growth and development of rice plants, which in turn leads to higher crop productivity.

\section{Acknowledgements}

The senior author sincerely acknowledges the Indian Agricultural Research Institute for the financial support in the form of Senior Research Fellowship for his Ph.D. research. Thanks are also due to the Head and Professor for providing field and laboratory facilities at the Division of Agronomy, IARI during the course of this investigation.

\section{References}

Alloway, B.J., 2008. Zinc in Soils and Crop Nutrition. International Zinc Association Publication. International Zinc Association, Brussels, Belgium.

Bisht, P.S., Pandey, P.C., Singh, D.K., 2006. Effect of different sources of nutrients on rice (Oryza sativa) yield and soil nutrient status in rice-wheat cropping. In: National Symposium on Conservation Agriculture and Environment, October 26-28, Banaras Hindu University, Varanasi, India.

Brar, M.S., Sekhon, G.S., 1976. Effect of Fe and Zn on the availability of micronutrients under flooded and unflooded condition. Journal of the Indian Society of Soil Science 24, 446-451.

Cakmak, I., 2004. Identification and correction of widespread zinc deficiency in Turkey-a success story (a NATO Science for Stability Project). Proceedings of the International Fertilizers Society 552, 1-26.

Dobermann, A., Fairhurst, T., 2000. Rice: Nutrient disorders and nutrient management. Handbook series. Potash \& Phosphate Institute (PPI), Potash \& Phosphate Institute of Canada (PPIC) and International Rice Research Institute. pp 192.

Evans, G.C., 1972. Quantitative analysis of growth. Blackwell Scientific Publication Oxford, London, UK.

Fageria, N.K., 2001. Screening method of lowland rice genotypes for zinc uptake efficiency. Scientia Agricola $58,623-626$.
Fertiliser Statistics 2012-13. The Fertiliser Association of India, FAI House, 10, Shaheed Jit Singh Marg, New Delhi.

Gomez, K.A., Gomez, A.A., 1984. Statistical procedures for agricultural research. Second Edition. John Wiley \& Sons, New York, USA.

Hanway, J.J., Heidel, H., 1952. Soil analysis methods as used in Iowa State College Soil Testing Laboratory. Bulletin 57, Iowa State College of Agriculture, Iowa, USA, pp 131.

Jensen, E.S., Hauggaard-Nielsen, H., 2003. How can increased use of biological $\mathrm{N}_{2}$ fixation in agriculture benefit the environment? Plant Soil 252, 177-186.

Kabata-Pendias, A., 2000. Trace elements in soils and plants, 3rd edn. CRC, Boca Raton, Florida, USA. pp. 58-72.

Karak, T., Singh, U.K., Das, S., Das, D.K., Kuzyakov, Y., 2005. Comparative efficacy of $\mathrm{ZnSO}_{4}$ and $\mathrm{Zn}$-EDTA application for fertilization of rice (Oryza sativa L.). Archives of Agronomy and Soil Science 51, 253-264.

Kirkegaard, J., Christen, O., Krupinsky, J., Layzell, D., 2008. Break crop benefits in temperate wheat production. Field Crops Research 107, 185-195.

Klug, A., Rhodes, D., 1987. 'Zinc fingers': A novel protein motif for nucleic acid recognition. Trends in Biochemical Sciences 12, 464-469.

Lindsay, W.L., Norvell, W.A., 1978. Development of DTPA soil test for zinc, iron, manganese and copper. Soil Science Society of America Journal 42, 421-428.

Mandal, B., Mandal, L.N., Ali, M.H., 1993. Chemistry of zinc availability in submerged soils in relation to zinc nutrition of rice crop. In: Proceedings of the workshop on micronutrients, Bhubaneswar, Odhisha, India, 22-23 January, pp 240-253.

Mandal, U.K., Singh, G., Victor, U.S., Sharma, K.L., 2003. Green manuring: Its effect on soil properties and crop growth under rice-wheat cropping system. European Journal of Agronomy 19, 225-237.

Mohammad, A., Hamad, R.J., Khan, E.A., Mohammad, R., 2005. Comparative response of diverse rice varieties to green manuring (Sesbania aculeata). Journal of Research (Science) 16, 39-43.

Mortvedt, J.J., 1979. Crop response to zinc sources applied alone or with suspensions. Fertilizer in Solution 23, 64-79.

Naik, S.K., Das, D.K., 2008. Relative performance of chelated zinc and zinc sulphate for lowland rice (Oryza sativa L.). Nutrient Cycling in Agroecosystems 81, 219-227.

Nayyar, V.K., Chhibba, I.M., 2000. Effect of green manuring on micronutrient availability in rice-wheat cropping system of northwest India. In: Long-term Soil Fertility Experiments in Rice-Wheat Cropping Systems. RiceWheat Consortium Paper Series 6, Abrol, I.P., Brown, 
K.F. (Eds.), New Delhi, India, pp. 68-72.

Olsen, R., Cole, C.V., Watanabe, F.S., Dean, L.A., 1954. Estimation of available phosphorus in soils by extraction with sodium bicarbonate. Circular-939 United States Department of Agriculture, Washington DC, USA.

Ortiz, E.M.E., Garcia, O.A., 1998. Process of sorption of zinc in three soils of Colombia cultivated with rice (Oryza sativa) of the dry land variety Llano-5. In: Proceedings of the VIII Congress of Soil Sciences, Santa Marta, Colombia. Suelos-Ecuatoriales, 28, 112-117.

Ozkutlu, F., Torun, B., Cakmak, I., 2006. Effect of zinc humate on growth of soybean and wheat in zinc-deficient calcareous soils. Communication in Soil Science and Plant Analysis 37, 2769-2778.

Pooniya, V., Shivay, Y.S., 2012. Summer green-manuring crops and zinc fertilization on productivity and economics of Basmati rice (Oryza sativa L.). Archives of Agronomy and Soil Science 58, 593-616.

Pooniya, V., Shivay, Y.S., Rana, A., Nain, L., Prasanna, R., 2012. Enhancing soil nutrient dynamics and productivity of Basmati rice through residue incorporation and zinc fertilization. European Journal of Agronomy 41, 28-37.

Prasad, R. 2006. Zinc in soils and in plants, human \& animal nutrition. Indian Journal of Fertilisers 2, 103-119.

Prasad, R., 2009. Zinc malnutrition and its alleviation through zinc fortified cereal grains. Proceedings of the Indian National Science Academy 75, 89-91.

Prasad, R., 2010. Zinc biofortification of food grains in relation to food security and alleviation of zinc malnutrition. Current Science 98, 1300-1304.

Prasad, R., Shivay, Y.S., Kumar, D., 2014. Agronomic biofortification of cereal grains with iron and zinc. Advances in Agronomy 125, 55-91.

Prasad, R., Shivay, Y.S., Kumar, D., Sharma, S.N., 2006. Learning by Doing Exercises in Soil Fertility (A practical manual for soil fertility), Division of Agronomy, Indian Agricultural Research Institute, New Delhi, India, pp-68.

Rattan, R.K., Shukla, L.M., 1991. Influence of different Zn carriers on the utilization of micronutrients by rice. Journal of the Indian Society of Soil Science 39, 808-810.

Robertson, G.P., Paul, E.A., Harwood, R.R., 2000. Greenhouse gases in intensive agriculture: Contributions of individual gases to the radioactive forcing of the atmosphere. Science 289, 1922-1925.

Sharma, S.N., Prasad, R., 1999. Effect of Sesbania greenmanuring and mungbean residue incorporation on productivity and nitrogen uptake of a rice-wheat cropping system. Bioresource Technology 87, 171-175.

Shivay, Y.S., Kumar, D., Prasad, R., Ahlawat, I.P.S., 2008. Relative yield and zinc uptake by rice from zinc sulphate and zinc oxide coatings onto urea. Nutrient Cycling in Agroecosystems 80(2), 181-188.

Shivay, Y.S., Prasad, R., Pal, M., 2014. Genetic variability for zinc use efficiency in chickpea as influenced by zinc fertilization. International Journal of Bio-resource and Stress Management 5(1), 31-36. DOI:10.5958/j.09764038.5.1.005

Singh, A.K., Khan, S.K., Nongkynrih, P., 1999. Transformation of zinc in wetland rice soils in relation to nutrition of crop. Journal of the Indian Society of Soil Science 47, 248-253.

Singh, M.V., Abrol, I.P., 1986. Transformation and availability of zinc in alkali soils. Fertiliser News 37, 17- 27.

Slaton, N.A., Gbur, E.E., Wilson, C.E., Norman, R.J., 2005a. Rice response to granular zinc sources varying in watersoluble zinc. Soil Science Society of America Journal 69, 443-452.

Slaton, N.A., Norman, R.J., Wilson, C.E., 2005b. Effect of zinc source and application time on zinc uptake and grain yield of flooded-irrigated rice. Agronomy Journal 97, 272-278.

Srivastava, P.C., Ghosh, D., Singh, V.P., 1999. Evaluation of different zinc sources for low land rice production. Biology and Fertility of Soils 30, 168-172.

Subbiah, B.V., Asija, G.L., 1956. A rapid procedure for the estimation of available nitrogen in soils. Current Science $25,259-260$.

Takkar, P.N., Singh, M.V., Ganeshmurthy, A.N., 1997. A critical review of plant nutrient supply needs, efficiency and policy issues for Indian agriculture for the year 2000: Micronutrients and Trace elements. In: Plant Nutrient, Supply Efficiency and Policy Issues: 2000-2025, Kanwar, J.S., Katyal, J.C. (Eds.) National Academy of Agricultural Sciences New Delhi, India. pp. 238-264.

Walkley, A.J., Black, I.A., (1934). An examination of the Degtjareff method for determination of soil organic matter and a proposed modification of the chromic acid titration method. Soil Science 37, 29-38.

Yadvinder-Singh, Khind, C.S., Bijay-Singh. 1991. Efficient management of leguminous green manures in wetland rice. Advances in Agronomy 45, 135-189. 